\title{
A Useful Model for Rainwater Catchment System Design
}

\author{
James Niffenegger \\ Senior, Mechanical Engineering \\ Harvard School of Engineering and Applied Sciences \\ Cambridge, MA 02138 \\ james.niffenegger@gmail.com \\ Avery Meyer, E.I.T. \\ Engineer I \\ WSP USA \\ 75 Arlington Street $9^{\text {th }}$ Floor, Boston, MA 02116 \\ averymeyer@gmail.com \\ Christopher Lombardo, Ph.D.* \\ Associate Director of Undergraduate Studies \\ Harvard School of Engineering and Applied Sciences \\ Cambridge, MA 02138 \\ lombardo@seas.harvard.edu \\ *Corresponding Author
}

\begin{abstract}
Choosing a storage volume size for a rainwater catchment project is difficult because the overall volume needs to be large enough to meet the demand of users but not so high that it is never completely filled, which would waste money and space in the community. This newly developed Excel-based model can simplify choosing appropriate tank sizes for a rainwater catchment project by projecting the water availability in storage at multiple locations over the course of a year. For ease of use, the user can input monthly or daily data for improved accuracy. This tool also incorporates the ability to include adjustable daily demand, to distribute demand over multiple structures, to account for tank overflow, and to increase demand at other locations if one of them runs out of water. The water level at each location over one year and the local storage volume are shown on a plot, making it easy to determine what storage volume is necessary to provide enough water for the community. This tool was originally developed to determine appropriate storage volumes for a rainwater catchment project in Mkutani, Tanzania and has been adapted for general use.
\end{abstract}

Index Terms: Rainwater catchment, rainwater harvesting, Excel modeling, project planning, Engineers Without Borders

\section{INTRODUCTION}

About 844 million people worldwide do not have access to a consistent source of clean water for drinking, sanitation, and hygiene. ${ }^{1}$ Of this number, 159 million collect untreated surface water from lakes, ponds, rivers, and streams, and 423 million use water from unprotected wells and springs. These contaminated sources have been linked to the transmission of diseases such as cholera, diarrhea, dysentery, hepatitis A, typhoid, and polio. ${ }^{2}$ As a result, these individuals are consistently exposed to deadly but preventable diseases. In addition, another 263 million people 
have access to clean water, but it takes more than 30 minutes to reach these sources. ${ }^{2}$ The time spent collecting water, which can take hours, reduces the time available for work and education for women and children, who are typically responsible for water collection. ${ }^{3-5}$

One approach to address water supply challenges such as these is through extracurricular service-learning programs such as Engineers Without Borders USA (EWB-USA), Engineers for a Sustainable World, and others. While initially these programs were purely extracurricular, many academic institutions have begun to incorporate them into their curricula in various ways, including a Humanitarian Design Project course offered through the Harvard School of Engineering and Applied Sciences (SEAS) ${ }^{6-8}$ One common method to address water supply issues is through rainwater catchment, which can be a very promising option; with proper design and management, these systems can provide accessible safe water. ${ }^{9}$ Additionally, these systems do not typically require extensive professional experience for their design and construction, which makes them suitable for volunteer-based service learning groups. In a rainwater catchment system, rainwater is collected from gutters on a roof and transported into a storage basin, usually a tank. Although rainwater is relatively contaminant free, it can be polluted by dirt, leaves, fecal matter, and insect bodies found on a roof or in gutters. ${ }^{9,10}$ A common way of removing some of these contaminants is to divert the first flow of rainwater, which carries most of the pollutants, into a separate storage area or first flush system. ${ }^{10}$ This first flush system can be part of the piping between the gutters and the tank, where it fills up first before water can reach the tank. To ensure that this system collects as many pollutants as possible, there is typically a valve or hole at the bottom that enables it to drain and which needs to be cleaned out regularly. ${ }^{11}$

Figure 1 shows a rainwater catchment system built in a collaboration between the Harvard SEAS and the Boston Professional chapters of EWB-USA for the primary school in Mkutani, Tanzania. In this system, water is collected from the roof into the gutters (shown in the yellow box), and then it flows into a first flush system (shown in the red box). Once the first flush system is filled, the rest of the water fills an adjacent tank.

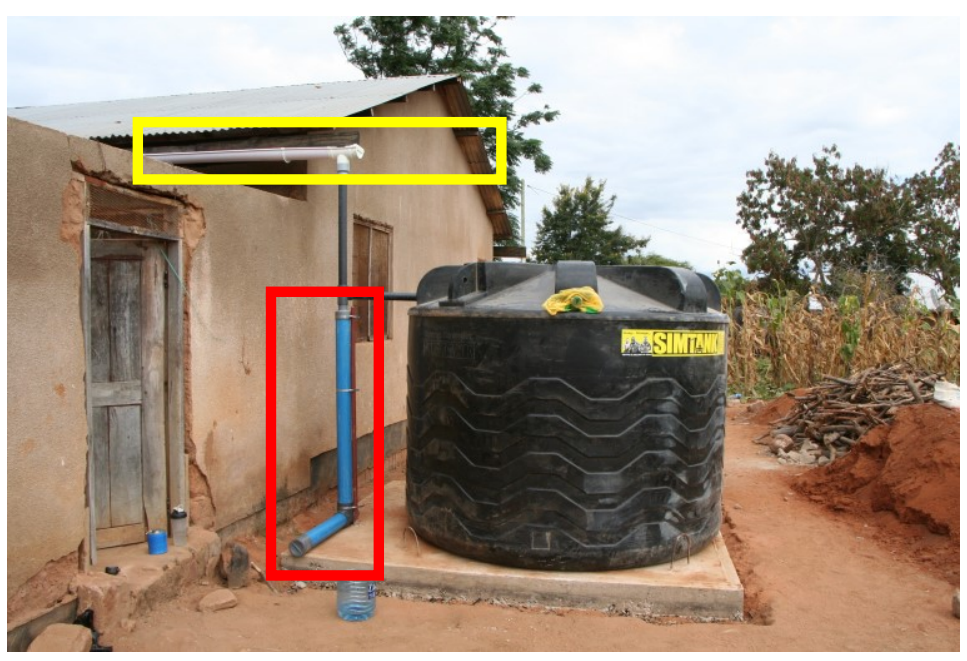

FIGURE 1

EXAMPLE RAINWATER CATCHMENT SYSTEM CONSTRUCTED IN MKUTANI, TANZANIA 
International Journal for Service Learning in Engineering, Humanitarian Engineering and Social Entrepreneurship Vol. 14, No. 3, Special Issue, pp. 80-97, Fall 2019

ISSN 1555-9033

\section{BACKGROUND}

In the fall of 2017, the Harvard SEAS and Boston Professional Chapters of EWB-USA began planning a rainwater catchment project for a primary school in Mkutani, Tanzania. The 600 students and 8 teachers at the school complex needed clean water for drinking, handwashing, and cooking. There were two sources of water in the community: a nearby contaminated river and a borehole several kilometers away. Using water from the river is convenient, but carries significant risks, as it is contaminated with agricultural chemicals, pesticides, and fecal matter. Since the nearby river water is unclean and potable water from the well is time-consuming to collect, many students had not been drinking water during the school day. The headmaster of the school believed that their dehydration affected their performance in class. For the teachers, needing to go to the borehole to collect water took up a significant amount of limited time that was necessary for teaching and preparing lessons for hundreds of students. By building a rainwater catchment facility at the school, a new accessible water source would be available for these users.

During the design phase of the project, the project team encountered a common question: What storage volume was necessary for the system? The answer to this question is important, because if the storage volume is too small, the system may not collect as much water as is required by the community, and if the storage volume is too large, the system could waste limited project funds and space in the community. A few minutes of research on the internet will produce several organizations working to assist groups trying to implement rainwater catchment systems. Examples include the American Rainwater Catchment Systems Association (ARCSA) or The Center for Rainwater Harvesting, both of which offer their own free downloadable Excel design tool. ${ }^{12,13}$ Other organizations such as Texas A\&M University's AgriLife Extension Service and the World Bank's Climate Change Knowledge Portal provide design information and rainfall data. ${ }^{14,15}$ Design tools help users estimate the quantity of storage required based on a given catchment area, runoff coefficient, and demand. By comparing the monthly volume of water provided to the monthly volume of water demanded, it is possible to minimize cost and optimize the design, where the chosen tank volume maximizes the days with water supply while minimizing the tank volume used given the data and design constraints.

While the Excel tools provided by ARCSA and The Center for Rainwater Harvesting can be helpful with smaller individualized systems and preliminary design, they fail to account for several variables that can have a significant impact when implementing more complex systems. Fluctuations in the number of people being served day-to-day and differences in each user's water needs can severely impact the quantity of water that must be stored. Satisfying a single demand with water from several discrete locations requires each system to be designed taking into account the other systems. Lastly, the inclusion of a first flush system will impact the volume of water being stored and needs to be sized on a site-specific basis. The rainwater catchment system implemented in the summer of 2018 in Mkutani had to account for all three of these variables. The following model was developed to assist with that and future designs.

\section{Model OVERVIEW}

In order address the aforementioned concerns, the authors chose to create an Excel-based model to resolve the issue of tank sizing for rainwater catchment projects. The goal was to design a rainwater catchment model to help determine an optimal storage volume in a community in order to reduce the number of days without water. After creating this model, the team was able to 
determine appropriate tank sizes for the community and has adapted the tool so that it can be used for other rainwater catchment projects.

To use the model, the user must input data about the rainfall, demand, details of the locations of the rainwater catchment system (such as the number of buildings used and aspects of the roofs), the tanks or storage volumes being considered, and the first flush systems. The tool then outputs the daily water level in storage at each location as well as the number of days without water in the community over the course of a design year. This "design year" is an estimate of how the system will work regardless of when it was constructed or last cleaned. Figure 2 shows the inputs and outputs of the rainwater catchment model.

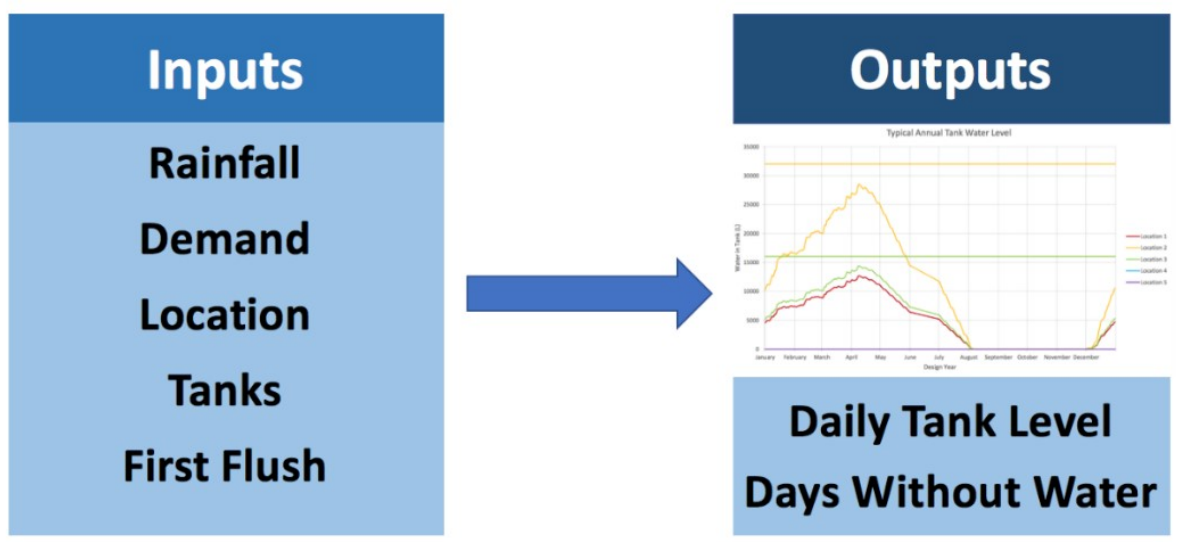

FIGURE 2

OVERVIEW OF MODEL INPUTS AND OUTPUTS

The Excel model has three main components: Preliminary Inputs, Final Inputs, and Tank Design. The Preliminary Inputs tab requires average monthly rainfall and demand data, which can be used for rough estimates and is useful for determining whether or not a rainwater catchment system is a worthwhile option for a community. The Final Inputs tab requires average daily rainfall and demand values, which can be used for more accurate estimates and is useful for determining what is necessary for implementing the system in a community. The Tank Design tab uses data from either the Preliminary Inputs or the Final Inputs tab, in addition to more information about the storage volume being considered and details about the locations used to estimate the water level in the tanks and the days without water.

\section{Preliminary InPUTS}

The average monthly rainfall data for the Preliminary Inputs tab can be found online at sources such as the World Bank Group's Climate Change Knowledge Portal. ${ }^{15}$ When using this source, the user chooses the location of their project on a map of the world and the time period or range of dates they want precipitation data from. An example of the map and associated rainfall data are shown in Figure 3. 


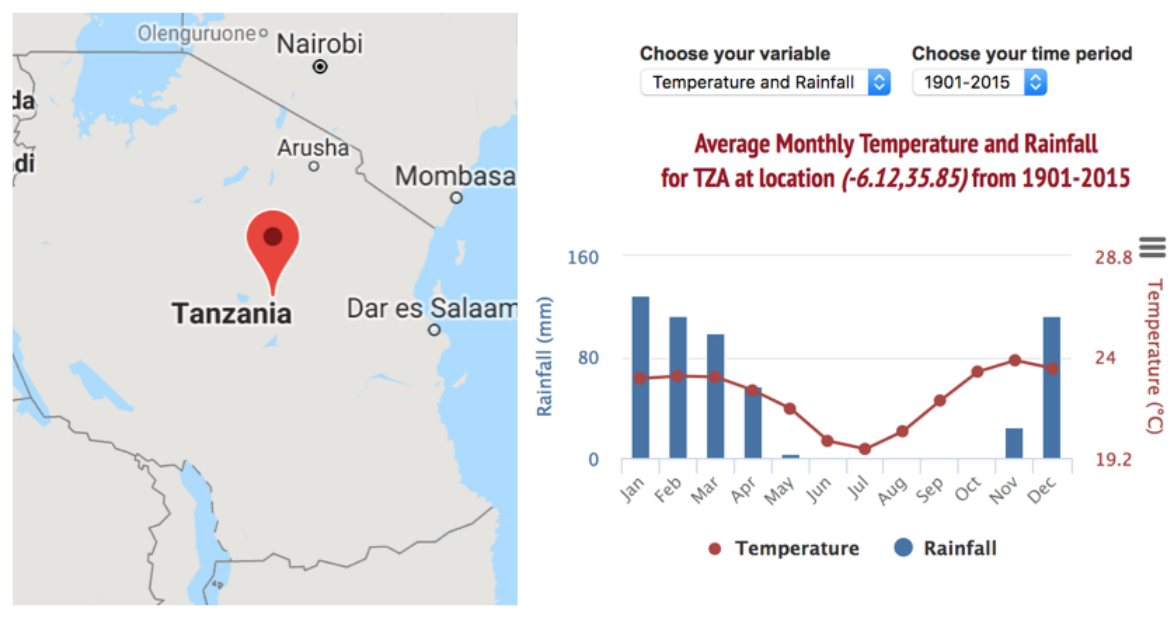

FIGURE 3

AVERAGE MONTHLY RAINFALL DATA COLLECTED FROM THE WORLD BANK GROUP'S CLIMATE CHANGE KNOWLEDGE PORTAL FOR THE PROJECT IN MKUTANI, TANZANIA ${ }^{15}$

After rainfall data are obtained, they need to be added to the orange input boxes in the "Average Total Monthly Rainfall" column in the "Average Monthly Rainfall Supply" section. This section also requires a minimum monthly rainfall input, which allows the user to separate the rainy season from the dry season. Since small amounts of rainfall do not provide enough volume to fill the first flush system and may only wet the roof, including these values can distort the tank analysis.

The Preliminary Demand inputs include the monthly number of users, the average demand per day per person, and the estimated waste factor. If it is unclear what the water demand is for the users, sources such as the World Health Organization (WHO) can provide guidelines for how much water an adult may need in various situations. For example, according to the WHO, if an adult only needs water for drinking, their daily demand is 10L per day, but if they need it for drinking, cooking, and bathing, their daily demand is $30 \mathrm{~L}$ per day. ${ }^{16}$ The waste factor is used to account for spills and system losses, such as leaks. The WHO recommends keeping this value at $10 \% .{ }^{16}$

Figure 4 shows the rainfall and demand inputs for the Preliminary Inputs tab. The values in this example were used for the project in Mkutani, Tanzania. Here, the minimum monthly rainfall was set to $20 \mathrm{~mm}$, but values between $20 \mathrm{~mm}$ and $50 \mathrm{~mm}$ are acceptable for this input. The users for this system included 600 students and 8 teachers. As shown, the teachers used the system yearlong, but the students would not use the system during June and December, as school is not in session and they can obtain water from the well with their families. It was estimated that the teachers needed 20L of water per day because they would use it for drinking and cooking, and students needed 1L of water per day for drinking and handwashing, based on observations made in the community during past projects. ${ }^{17}$ The $10 \%$ waste factor is a standard value. ${ }^{16}$ 
International Journal for Service Learning in Engineering, Humanitarian Engineering and Social Entrepreneurship Vol. 14, No. 3, Special Issue, pp. 80-97, Fall 2019 ISSN $1555-9033$

\begin{tabular}{|c|c|c|c|c|c|c|c|}
\hline \multicolumn{4}{|c|}{ Average Monthly Rainfall Supply } & \multicolumn{4}{|c|}{ Daily Water Demand } \\
\hline \multicolumn{2}{|c|}{$\left.{ }^{*}\right)$ Min. Monthly Rainfall $=$} & 20 & $\mathrm{~mm}$ & \multicolumn{2}{|c|}{$(+)$ Waste Factor $=$} & 10 & $\%$ \\
\hline Month & $\begin{array}{c}\text { Average } \\
\text { Total } \\
\text { Monthly } \\
\text { Rainfall } \\
(\mathrm{mm})\end{array}$ & $\begin{array}{c}\text { Design } \\
\text { Total } \\
\text { Monthly } \\
\text { Rainfall } \\
(\mathrm{mm})\end{array}$ & & Month & $\begin{array}{c}\text { Monthly } \\
\text { Users } \\
\text { (ea) }\end{array}$ & $\begin{array}{l}\text { Demand } \\
\text { per Day } \\
\text { per } \\
\text { Person } \\
\text { (L) }\end{array}$ & $\begin{array}{c}\text { Total } \\
\text { Daily } \\
\text { Demand } \\
\text { (L) }\end{array}$ \\
\hline January & 119.7 & 119.69 & & January & 608 & 1.25 & 836 \\
\hline February & 109.4 & 109.39 & & February & 608 & 1.25 & 836 \\
\hline March & 109.8 & 109.81 & & March & 608 & 1.25 & 836 \\
\hline April & 69.2 & 69.21 & & April & 608 & 1.25 & 836 \\
\hline May & 10.9 & 0 & & May & 608 & 1.25 & 836 \\
\hline June & 1.3 & 0 & & June & 8 & 20 & 176 \\
\hline July & 0.5 & 0 & & July & 608 & 1.25 & 836 \\
\hline August & 0.0 & 0 & & August & 608 & 1.25 & 836 \\
\hline September & 1.1 & 0 & & September & 608 & 1.25 & 836 \\
\hline October & 2.9 & 0 & & October & 608 & 1.25 & 836 \\
\hline November & 27.6 & 27.6 & & November & 608 & 1.25 & 836 \\
\hline December & 123.8 & 123.82 & & December & 8 & 20 & 176 \\
\hline
\end{tabular}

FIGURE 4

PRELIMINARY RAINFALL AND DEMAND INPUTS

After receiving all of the necessary inputs from the user, the Preliminary Inputs tab outputs a graph of the Preliminary Supply (the daily rainfall over a year) and the Preliminary Demand (the average daily demand over a year). Figure 5 shows the graphs of Preliminary Supply and Preliminary Demand outputted by the Preliminary Inputs tab. These graphs appear as stepwise functions, as they use average daily values from the monthly inputs. For example, the monthly inputs for rainfall are divided by the number of days in each month to determine daily data points for the Preliminary Supply graph. Meanwhile, the Preliminary Demand graph already has average daily values per month as inputs.
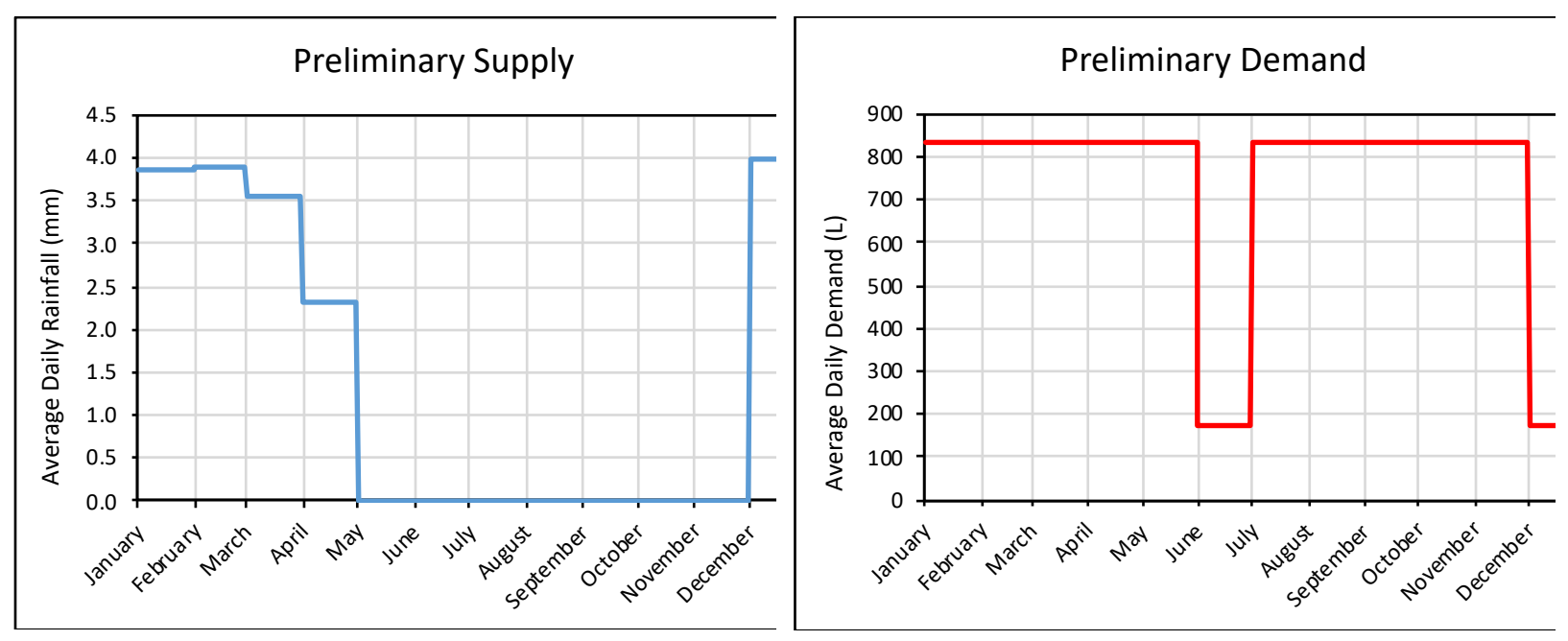

FIGURE 5

OUTPUTS OF THE PRELIMINARY INPUTS TAB: PRELIMINARY SUPPLY AND PRELIMINARY DEMAND 
International Journal for Service Learning in Engineering, Humanitarian Engineering and Social Entrepreneurship Vol. 14, No. 3, Special Issue, pp. 80-97, Fall 2019

ISSN 1555-9033

\section{FINAL INPUTS}

\section{Average Rainfall Analysis}

The daily rainfall data for the Final Inputs tab can be found online at sources such as Texas A\&M University's Global Weather Database. ${ }^{18}$ When using this source, the user creates a box over a region on a world map to include the nearest weather station to their project's location. They can then request daily precipitation data from 1979 to 2014. However, for this model, it is recommended to use data from 1994 to 2013, since 2014 does not have a complete year of data. Figure 6 shows an example of using the Global Weather Database for Mkutani, Tanzania. The blue box in this case covers two stations to more clearly illustrate the selection tool.

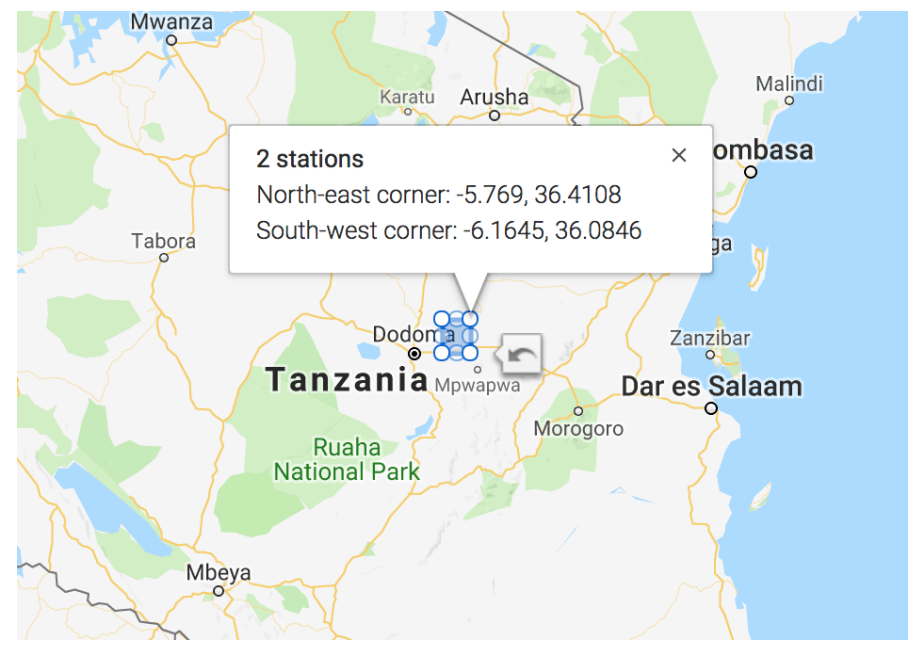

FIGURE 6

AN EXAMPLE OF USING THE GLOBAL WEATHER DATABASE FOR MKUTANI, TANZANIA ${ }^{18}$

After the data are downloaded, the user needs to remove leap days, i.e. February 29th, from the data set, which can easily be done in Microsoft Excel by deleting the respective rows. The daily rainfall values for up to 20 years can then be copied and pasted into the "Average Rainfall Analysis Tool", another Excel file which comes with the model package. It is provided as an optional resource since the method used to average rainfall data should be site and use-specific. This additional tool averages up to 20 years of data. If fewer than 20 years are used, an accurate average is still returned and provides an estimate for a dry year and a rainy year. The estimate for a dry year is based on the mean values minus the standard deviation of the data, while the rainy year is based on the mean plus the standard deviation. Although typically it is recommended to use the average year estimates, users can input these estimates (from a dry or rainy year) or data from one year into the model. Figure 7 shows the inputs and outputs for the Average Rainfall Analysis Tool. The data used in this example are from the weather station near Mkutani, Tanzania. Although the tool allows up to 20 years of data, this example shows only 6 so that the figure is more visible. With this data, the tool produces daily rainfall values for an average year, dry year, and rainy year. The average year is highlighted in green; these data are the most useful input for the model. 
International Journal for Service Learning in Engineering, Humanitarian Engineering and Social Entrepreneurship Vol. 14, No. 3, Special Issue, pp. 80-97, Fall 2019

\begin{tabular}{|c|c|c|c|c|c|c|c|c|c|c|c|c|}
\hline \multicolumn{3}{|c|}{ Design Year Calendar } & \multicolumn{6}{|c|}{ Daily Rainfall Data (mm) } & \multirow{3}{*}{$\begin{array}{l}\text { SD Factor } \\
(\mu+\sigma) / \mu \\
-1\end{array}$} & \multicolumn{3}{|c|}{ Design Rainfall Data (mm) } \\
\hline \multirow{2}{*}{ Day } & \multirow{2}{*}{ Month } & \multirow{2}{*}{$\begin{array}{l}\text { Day of } \\
\text { Week }\end{array}$} & \multicolumn{6}{|c|}{ Year } & & \multirow{2}{*}{$\begin{array}{c}\text { Average } \\
\text { Year }\end{array}$} & \multirow{2}{*}{$\begin{array}{l}\text { Dry } \\
\text { Year }\end{array}$} & \multirow{2}{*}{$\begin{array}{l}\text { Rainy } \\
\text { Year }\end{array}$} \\
\hline & & & 2001 & 2002 & 2003 & 2004 & 2005 & 2006 & & & & \\
\hline 1 & \multirow{18}{*}{ Jan } & $\mathrm{M}$ & 1.62 & 0.02 & 10.12 & 0.10 & 0.96 & 0.00 & 0.29 & 1.43 & 1.02 & 1.84 \\
\hline 2 & & $\mathrm{~T}$ & 4.39 & 0.16 & 47.80 & 0.00 & 0.03 & 0.00 & 0.29 & 6.64 & 4.72 & 8.56 \\
\hline 3 & & W & 2.67 & 2.27 & 6.87 & 1.98 & 0.68 & 0.00 & 0.29 & 5.69 & 4.04 & 7.33 \\
\hline 4 & & Th & 10.27 & 1.78 & 5.34 & 2.45 & 5.51 & 0.03 & 0.29 & 3.45 & 2.45 & 4.45 \\
\hline 5 & & $\mathrm{~F}$ & 0.27 & 0.31 & 5.58 & 1.12 & 3.73 & 0.11 & 0.29 & 2.43 & 1.73 & 3.13 \\
\hline 6 & & Sat & 5.71 & 0.00 & 0.79 & 0.05 & 3.16 & 0.03 & 0.29 & 3.20 & 2.28 & 4.13 \\
\hline 7 & & Sun & 10.12 & 0.00 & 3.25 & 0.19 & 0.24 & 0.05 & 0.29 & 5.01 & 3.56 & 6.45 \\
\hline 8 & & $M$ & 1.22 & 0.00 & 0.02 & 0.26 & 0.01 & 0.09 & 0.29 & 7.75 & 5.51 & 9.99 \\
\hline 9 & & $\mathrm{~T}$ & 2.06 & 0.00 & 3.24 & 0.09 & 0.53 & 0.22 & 0.29 & 2.15 & 1.53 & 2.77 \\
\hline 10 & & W & 2.10 & 0.00 & 9.51 & 0.04 & 0.44 & 0.00 & 0.29 & 5.29 & 3.76 & 6.82 \\
\hline 11 & & Th & 22.39 & 0.13 & 3.75 & 1.22 & 3.06 & 0.66 & 0.29 & 7.76 & 5.52 & 10.01 \\
\hline 12 & & $F$ & 1.30 & 7.69 & 0.00 & 0.29 & 0.77 & 3.10 & 0.29 & 4.32 & 3.07 & 5.57 \\
\hline 13 & & Sat & 6.93 & 15.48 & 0.00 & 0.66 & 0.05 & 1.27 & 0.29 & 9.19 & 6.53 & 11.84 \\
\hline 14 & & Sun & 13.73 & 6.45 & 0.00 & 4.89 & 0.87 & 0.00 & 0.29 & 4.67 & 3.32 & 6.02 \\
\hline 15 & & $M$ & 3.09 & 12.67 & 0.00 & 9.12 & 1.53 & 0.00 & 0.29 & 4.39 & 3.12 & 5.66 \\
\hline 16 & & $\mathrm{~T}$ & 0.38 & 1.70 & 0.17 & 1.71 & 0.15 & 0.37 & 0.29 & 3.80 & 2.70 & 4.90 \\
\hline 17 & & W & 2.56 & 2.31 & 4.38 & 0.36 & 0.34 & 2.96 & 0.29 & 4.49 & 3.19 & 5.79 \\
\hline 18 & & Th & 7.68 & 5.82 & 5.77 & 0.05 & 0.34 & 0.56 & 0.29 & 2.68 & 1.90 & 3.45 \\
\hline
\end{tabular}

FIGURE 7

AVERAGE RAINFALL ANALYSIS TOOL AND RESULTS FOR MKUTANI, TANZANIA

\section{Daily Water Demand}

The Final Demand inputs are similar to the Preliminary Demand inputs; however, this tab enables the user to define up to three different user groups with a different number of users and different levels of demand. The waste factor is also included in this tab. Figure 8 shows the demand inputs for the Final Inputs tab. This example shows the needs of the two user groups for the project in Mkutani, Tanzania. User Group 1 represents the teachers, while User Group 2 represents the students. In this case, the third group was not necessary but was left available as an option for other users of the model.

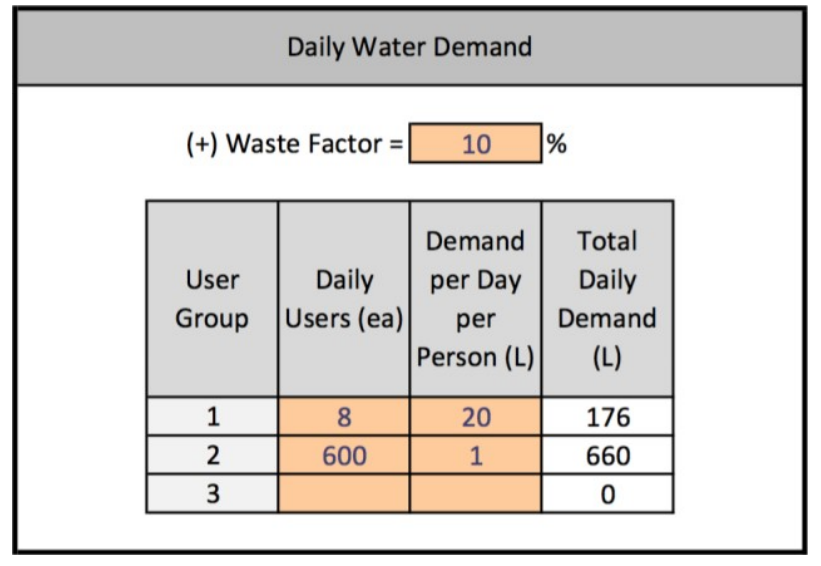

FIGURE 8

FINAL DAILY WATER DEMAND INPUTS 
International Journal for Service Learning in Engineering, Humanitarian Engineering and Social Entrepreneurship Vol. 14, No. 3, Special Issue, pp. 80-97, Fall 2019

ISSN 1555-9033

\section{Water Demand Index}

After completing these steps, the user can then fill out the "Input Daily Data" section of the tab. Here, the daily rainfall generated by the "Average Rainfall Analysis Tool" can be inputted into the "Average Daily Rainfall" column. To complete the demand inputs, the "Demand User Index" for each group must be defined. This index is used to account for known periods that a group will not use water from the system. A " 1 " indicates that they will use it that day and a " 0 " indicates that they will not. If the group will use it year-round, then the whole index column should be ones, but if it is known that one group will not use it certain days of the week or months of the year, then zeros will be used. This index can be easily changed by copying and pasting values down a column. The user can also indicate which day of the week is the first day of the design year for proper indexing.

Figure 9 shows the average daily rainfall and daily demand inputs for the Final Inputs tab. This example shows the rainfall data and indexing used for the Mkutani project. Since the teachers in user group 1 would use the system yearlong, their column displays ones. However, since the students would not use the system on weekends, their index displays zeros for those days. Additionally, since they would not use the system during their breaks in June and December, the days in those months have zeros as well.

\begin{tabular}{|c|c|c|c|c|c|c|c|c|}
\hline \multicolumn{9}{|c|}{ Input Daily Data } \\
\hline \multicolumn{2}{|c|}{ Calendar } & \multicolumn{3}{|c|}{ Rainfall Supply Input } & \multicolumn{4}{|c|}{ Water Demand User Index } \\
\hline Date & $\begin{array}{l}\text { Day of } \\
\text { Week }\end{array}$ & $\begin{array}{c}\text { Average } \\
\text { Daily } \\
\text { Rainfall } \\
(\mathrm{mm})\end{array}$ & $\begin{array}{c}\text { Average } \\
\text { Monthly } \\
\text { Rainfall } \\
(\mathrm{mm})\end{array}$ & $\begin{array}{c}\text { Design } \\
\text { Daily } \\
\text { Rainfall } \\
\text { (mm) }\end{array}$ & $\begin{array}{c}\text { User } \\
\text { Group } 1 \\
\text { Index }\end{array}$ & $\begin{array}{c}\text { User } \\
\text { Group } 2 \\
\text { Index }\end{array}$ & $\begin{array}{c}\text { User } \\
\text { Group } 3 \\
\text { Index }\end{array}$ & $\begin{array}{c}\text { Design } \\
\text { Water } \\
\text { Demand } \\
\text { (L) }\end{array}$ \\
\hline $\operatorname{Jan} 1$ & $M$ & 1.43 & \multirow{18}{*}{120.11} & 1.43 & 1 & 1 & & 836 \\
\hline $\operatorname{Jan} 2$ & $\mathrm{~T}$ & 6.64 & & 6.64 & 1 & 1 & & 836 \\
\hline $\operatorname{Jan} 3$ & W & 5.69 & & 5.69 & 1 & 1 & & 836 \\
\hline $\operatorname{Jan} 4$ & Th & 3.45 & & 3.45 & 1 & 1 & & 836 \\
\hline $\operatorname{Jan} 5$ & $\mathrm{~F}$ & 2.43 & & 2.43 & 1 & 1 & & 836 \\
\hline $\operatorname{Jan} 6$ & Sat & 3.20 & & 3.20 & 1 & 0 & & 176 \\
\hline $\operatorname{Jan} 7$ & Sun & 5.01 & & 5.01 & 1 & 0 & & 176 \\
\hline $\operatorname{Jan} 8$ & $M$ & 7.75 & & 7.75 & 1 & 1 & & 836 \\
\hline $\operatorname{Jan} 9$ & $\mathrm{~T}$ & 2.15 & & 2.15 & 1 & 1 & & 836 \\
\hline $\operatorname{Jan} 10$ & W & 5.29 & & 5.29 & 1 & 1 & & 836 \\
\hline $\operatorname{Jan} 11$ & Th & 7.76 & & 7.76 & 1 & 1 & & 836 \\
\hline $\operatorname{Jan} 12$ & $F$ & 4.32 & & 4.32 & 1 & 1 & & 836 \\
\hline $\operatorname{Jan} 13$ & Sat & 9.19 & & 9.19 & 1 & 0 & & 176 \\
\hline $\operatorname{Jan} 14$ & Sun & 4.67 & & 4.67 & 1 & 0 & & 176 \\
\hline $\operatorname{Jan} 15$ & $M$ & 4.39 & & 4.39 & 1 & 1 & & 836 \\
\hline $\operatorname{Jan} 16$ & $\mathrm{~T}$ & 3.80 & & 3.80 & 1 & 1 & & 836 \\
\hline $\operatorname{Jan} 17$ & W & 4.49 & & 4.49 & 1 & 1 & & 836 \\
\hline $\operatorname{Jan} 18$ & Th & 2.68 & & 2.68 & 1 & 1 & & 836 \\
\hline
\end{tabular}

FIGURE 9

FINAL RAINFALL AND DEMAND INPUTS WITH USER INDEXING

\section{Model Output}

After receiving all of the necessary inputs from the user, the Final Inputs tab outputs a graph of the Final Supply, showing the average daily rainfall over a year, and the Final Demand, showing the daily demand over a year. Figure 10 shows plots of the Final Supply and Final Demand 
outputted by the Final Inputs tab. The Final Supply graph is flat during the dry season, as this tab also has a minimum rainfall input, and the Final Demand graph values vary due to differences in the demand indexes of the two user groups. These graphs are more precise than the preliminary graphs since they reflect more specific estimations.
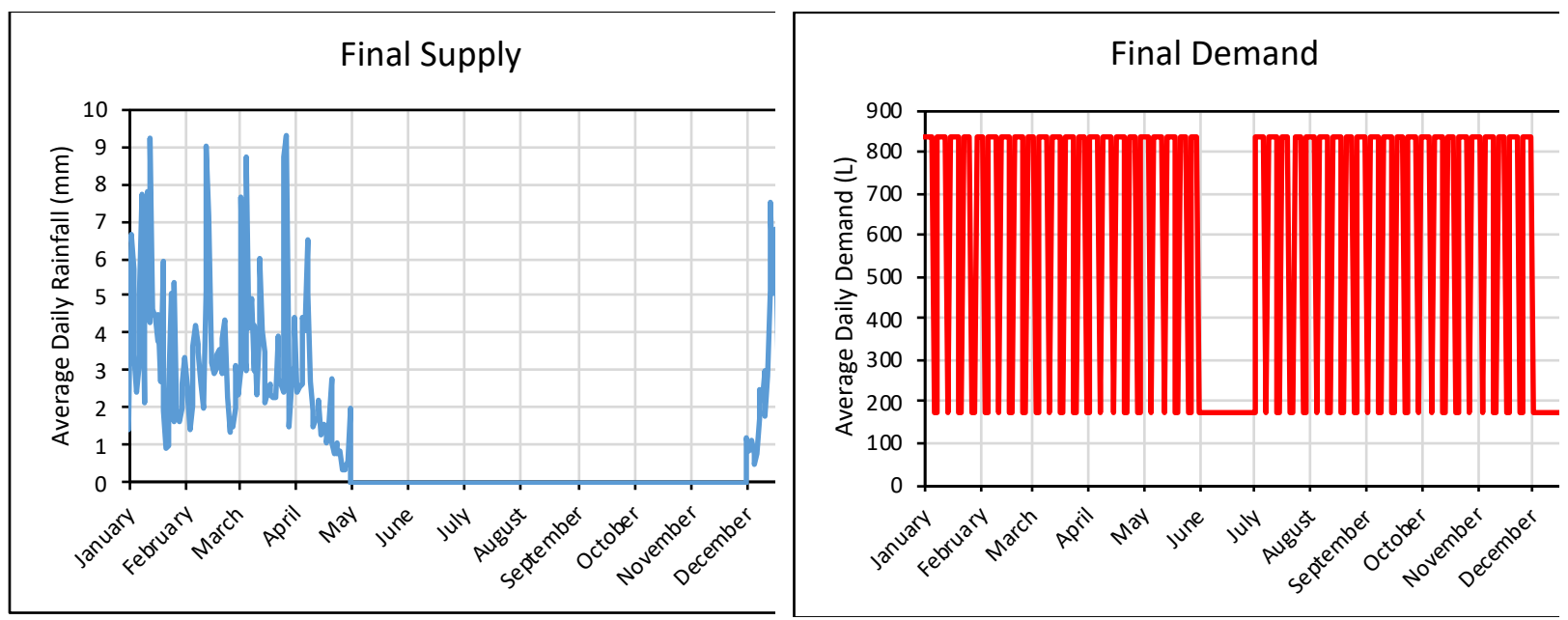

FIGURE 10

OUTPUTS OF THE FINAL INPUTS TAB: FINAL SUPPLY AND FINAL DEMAND

\section{TANK DESIGN}

\section{Tank Design Inputs}

The location, first flush volume, and storage volume inputs for the Tank Design tab are projectspecific and need to be determined by the project teams. The first decision for the user is what set of input data will be used for the analysis. The user can choose between the Preliminary and Final data from a drop-down menu at the top of the "Input Parameters" section.

The next input is the number of distinct locations being used for the system. This allows the designer to use separate catchment systems to satisfy a single demand. If two roofs from two different buildings are used, but they connect to the same storage volume, then they are considered one location. Up to five locations can be chosen for this model. The roof area is not the surface area of the roof; it is the two-dimensional projection of the roof. For a rectangular roof, the roof area for this tab is the length multiplied by the width; the angle of the roof is disregarded. This is a standard method of estimation for rainwater catchment projects and is appropriate; because the rain comes from above the roof, the area it lands on is equivalent to this projection. ${ }^{14}$

Choosing the roof type for a given location from the drop-down list in the tool prompts the model to suggest a runoff coefficient. The runoff coefficient is the ratio of the volume of water that runs off the roof into the tank to the total volume of water that lands on the roof. This accounts for water losses due to evaporation and saturation and is based on the roof slope and material. A high value translates to fewer losses. ${ }^{19}$ The suggested runoff coefficients presented in Table I are 
International Journal for Service Learning in Engineering, Humanitarian Engineering and Social Entrepreneurship Vol. 14, No. 3, Special Issue, pp. 80-97, Fall 2019

ISSN 1555-9033

approximated from literature estimations, but due to the variability of estimates, the user must input what is accurate for their location in the "User Runoff Coefficient" column.

TABLE I

RUNOFF COEFFICIENTS FOR VARIOUS ROOF TYPES

\begin{tabular}{|l|c|}
\hline Roof Type & Runoff Coefficient $(\boldsymbol{C})$ \\
\hline Metal & $92 \%$ \\
\hline Plastic & $91 \%$ \\
\hline Clay Tiles & $84 \%$ \\
\hline Concrete & $90 \%$ \\
\hline Flat & $80 \%$ \\
\hline
\end{tabular}

Next, the user needs to determine and input the expected volume of the first flush system. This input was left to be user-defined since there is a large range of ratios for first flush volume to roof area, which depend on the level of debris on a roof. This is a function of the number of dry days, type and amount of debris, and season. ${ }^{10}$ Since it is difficult to quantify all of the relevant factors for first flush sizing, any calculated first flush size generated by the model could be inaccurate and misleading for users. Sizing the First Flush and its Effect on the Storage-Reliability Yield Behavior of Rainwater Harvesting in Rwanda by Doyle Kelly provides valuable information on the factors involved in first flush design and can be used by users to develop an effective first flush design given the specific conditions of their project. ${ }^{11}$

Since the intent of a first flush system is to divert contaminated water at the start of a rain event away from the storage tank, the system needs to be able to drain between rainstorms. ${ }^{20}$ The drain rate is the quantity of water that leaves the first flush system per day. This is usually accomplished through a hole or valve at the bottom of the first flush system. ${ }^{10}$ Although the drain rate must be assumed by the user, it is possible to use the model to test how the first flush system operates based on an assumed volume and drain rate. This requires the user to input a single year's worth of rainfall data, rather than an average design year, so that the dry days between storms are accounted for. Reviewing the daily water level in the first flush system can help inform the decision of what volume and drain rate should be used. Since drainage is typically accomplished by a small hole or opening at the bottom of the first flush system, only small contaminants are drained from the system. Therefore the system must be cleaned of larger solid pollutants between rainstorms, when there is a day or two between rainfall. ${ }^{10}$

The final input for this system is the proposed total storage volumes at each location. This is user-defined because a team may not be able to afford or fit an optimal storage volume in a particular community. Logistical concerns aside, with this feature, a design team can still estimate how long the water supply will provide water for a community. The optimal storage volume can still be determined using this tool and varying the volume inputs, which will be discussed in a later section.

Figure 11 shows the location, first flush volume, and storage volume inputs for the tank design tab. This example shows the parameters used for the Mkutani project, where three locations were used: the primary school Headmaster's house, a classroom building, and a teachers' house respectively. All of the locations had metal roofs and a slightly lower runoff coefficient was used since the material was likely rougher than that used for the literature estimate. ${ }^{19}$ The first flush 
volume was determined from a first flush volume to roof area ratio and consideration of the local available piping. ${ }^{10}$ The drain rate was estimated and shall be verified in-country based on the time it takes to fill a known volume. The total storage volumes shown represent the combined volumes of locally available $8000 \mathrm{~L}$ tanks and are the optimal storage volumes for the locations in this community.

\begin{tabular}{|c|c|c|c|c|c|c|c|}
\hline \multicolumn{8}{|c|}{ Input Parameters } \\
\hline \multicolumn{5}{|c|}{ Select Preliminary or Final Design Data: } & \multirow{2}{*}{\begin{tabular}{|l} 
Final \\
Preliminary \\
Final
\end{tabular}} & $\nabla$ & \multirow[b]{3}{*}{$\begin{array}{c}\text { Total } \\
\text { Storage } \\
\text { Volume (L) }\end{array}$} \\
\hline \multicolumn{5}{|c|}{ System Design } & & \multirow[b]{2}{*}{$\begin{array}{l}\text { First Flush } \\
\text { Drain Rate } \\
\text { (L/day) }\end{array}$} & \\
\hline Location & $\begin{array}{c}\text { Roof Area } \\
\left(\mathrm{m}^{2}\right)\end{array}$ & Roof Type & $\begin{array}{c}\text { Suggest } \\
\text { Runoff } \\
\text { Coeff. }\end{array}$ & $\begin{array}{c}\text { User } \\
\text { Runoff } \\
\text { Coeff. }\end{array}$ & $\begin{array}{l}\text { First Flush } \\
\text { Volume } \\
\text { (L) }\end{array}$ & & \\
\hline 1 & 70.27 & Metal & 0.92 & 0.9 & 28.62 & 5.00 & 16000 \\
\hline 2 & 156.16 & Metal & 0.92 & 0.9 & 63.59 & 5.00 & 32000 \\
\hline 3 & 79.57 & Metal & 0.92 & 0.9 & 32.40 & 5.00 & 16000 \\
\hline \multicolumn{8}{|l|}{4} \\
\hline 5 & & & & & & & \\
\hline
\end{tabular}

FIGURE 11

INPUTS FOR THE TANK DESIGN TAB

\section{Water Level Calculations}

After receiving all of the inputs, the Tank Design tab then calculates a variety of factors to determine the volume of water remaining in a tank or storage daily at each of the locations over the course of three years. The rainwater supplied to the system on a given day $\left(i^{\text {th }}\right)$ at given location $\left(\mathrm{n}^{\text {th }}\right)$ can be found using:

$$
S_{r, i}=P_{i} * \frac{1 m}{1000 m m} * A_{i} * \frac{1000 L}{1 m^{3}} * C_{r, i}
$$

where $S_{r, i}$ is the rainwater supplied today (L), $P_{i}$ is precipitation today (mm), $A_{i}$ is the projected roof area $\left(\mathrm{m}^{2}\right)$, and $C_{r, i}$ is the runoff coefficient. The volume of water supplied to the tank can be found by subtracting the water lost to the first flush system from the rainwater supplied today, as shown in the following relation:

$$
S_{t, i}=S_{r, i}-D_{f f, i}
$$

where $S_{t, i}$ is the rainwater supplied to the tank today (L) and $D_{f f, i}$ is the water lost to the first flush system today (L).

The water that is lost to user demand is calculated by considering the area demand factor. This factor is meant to distribute the total demand across all of the catchment/storage locations and represents the ratio of the volume of water stored in a location yesterday to the total storage volume 
of the project yesterday, since more people are likely to use tanks in areas that are filled with more water. The relation for the area demand factor is:

$$
\alpha_{i}=\frac{V_{t,(i-1)}}{\sum_{n=1}^{5} V_{t,(i-1)}^{n}}
$$

where $\alpha_{i}$ is the percentage of total demand today at a specific location, $V_{t,(i-1)}$ is the volume of water in storage yesterday at a specific location (L), and $\sum_{n=1}^{5} V_{t,(i-1)}^{n}$ is the summation of the volume of water in storage yesterday at each location in the project $(\mathrm{L})$. The daily demand at a specific location is then calculated by multiplying the total water demand for the entire project by the percentage of water demand calculated above. The relation for the daily demand is:

$$
D_{i}=\alpha_{i} * D_{T o t, i}
$$

where $D_{i}$ is the daily water demand (L) and the $D_{T o t, i}$ is the water demand for all locations at the project site $(\mathrm{L})$. Finally, the volume of water in the tanks or storage is determined by subtracting the water supplied to the tank by the daily demand at the location as show below:

$$
V_{t, i}=\operatorname{MIN}\left(\operatorname{MAX}\left(V_{t,(i-1)}+S_{t, i}-D_{i}, 0\right), L_{t}\right)
$$

where $V_{t, i}$ is the water level in the tank (L) and $L_{t}$ is the maximum storage volume of the tank (L). The water level in the tank is limited by the amount of storage or tank volume to result in a more realistic estimate, since this water would overflow.

Figure 12 shows the calculations performed in the tank design tab for location 1, the Headmaster's house for the Mkutani project. Three important calculations in this section are the area demand factor, the water in the first flush system, and the water in the tank. Each column is in orange, green, and blue respectively. The area demand factor shows the percent of overall demand at the location. The "Water in First Flush" column is useful for designing the first flush system; however, since rainfall data from an average year are used for this example, the water in the first flush system is constant, as there are no dry days in the averaged rainy season. This makes the first flush system similar to a constant demand rather than a helpful indicator. To take advantage of this information, a non-averaged year needs to be used so that the first flush system can be significantly drained between periods of storms without greatly impacting the volume of water going into the tank. The "Water in Tank" column shows the storage volume at each location. 
International Journal for Service Learning in Engineering, Humanitarian Engineering and Social Entrepreneurship Vol. 14, No. 3, Special Issue, pp. 80-97, Fall 2019

ISSN 1555-9033

\begin{tabular}{|c|c|c|c|c|c|c|c|c|c|c|c|c|c|c|}
\hline \multicolumn{2}{|c|}{ Calendar } & \multicolumn{2}{|c|}{ Supply \& Demand } & \multicolumn{10}{|c|}{ Location 1} & \multirow[b]{2}{*}{$\begin{array}{l}\text { Water in } \\
\text { Tank (L) }\end{array}$} \\
\hline \multirow[t]{2}{*}{ Date } & \multirow[t]{2}{*}{$\begin{array}{l}\text { Day of } \\
\text { Week }\end{array}$} & \multirow[t]{2}{*}{$\begin{array}{c}\text { Design Daily } \\
\text { Rainfall } \\
(\mathrm{mm})\end{array}$} & \multirow[t]{2}{*}{$\begin{array}{l}\text { Design } \\
\text { Water } \\
\text { Demand } \\
\text { (L) }\end{array}$} & $\begin{array}{c}\text { Roof Area } \\
\left(\mathrm{m}^{2}\right)\end{array}$ & $\begin{array}{c}\text { Runoff } \\
\text { Coeff. }\end{array}$ & $\begin{array}{l}\text { Roof } \\
\text { Supply } \\
\text { (L) }\end{array}$ & $\begin{array}{l}\text { First Flush } \\
\text { Volume } \\
\text { (L) }\end{array}$ & $\begin{array}{c}\text { Water } \\
\text { Lost to } \\
\text { First Flush } \\
\text { (L) }\end{array}$ & $\begin{array}{l}\text { Water } \\
\text { Supplied } \\
\text { to Tank } \\
\text { (L) }\end{array}$ & $\begin{array}{c}\text { Area } \\
\text { Demand } \\
\text { Factor }\end{array}$ & $\begin{array}{c}\text { Daily } \\
\text { Demand } \\
\text { (L) }\end{array}$ & $\begin{array}{l}\text { Water in } \\
\text { First Flush } \\
\text { (L) }\end{array}$ & $\begin{array}{l}\text { Tank } \\
\text { Volume } \\
\text { (L) }\end{array}$ & \\
\hline & & & & 70.27 & $90 \%$ & & 29 & & & & & 0 & 16000 & 0 \\
\hline \multicolumn{15}{|l|}{ Year 1 } \\
\hline $\operatorname{Jan} 1$ & $M$ & 1.43 & 836 & 70.27 & $90 \%$ & 90 & 29 & 29 & 62 & $0.00 \%$ & 0 & 24 & 16000 & 62 \\
\hline $\operatorname{Jan} 2$ & $\mathrm{~T}$ & 6.64 & 836 & 70.27 & $90 \%$ & 420 & 29 & 5 & 415 & $22.96 \%$ & 192 & 24 & 16000 & 285 \\
\hline $\operatorname{Jan} 3$ & W & 5.69 & 836 & 70.27 & $90 \%$ & 360 & 29 & 5 & 355 & $22.84 \%$ & 191 & 24 & 16000 & 449 \\
\hline $\operatorname{Jan} 4$ & Th & 3.45 & 836 & 70.27 & $90 \%$ & 218 & 29 & 5 & 213 & $22.86 \%$ & 191 & 24 & 16000 & 471 \\
\hline $\operatorname{Jan} 5$ & $\mathrm{~F}$ & 2.43 & 836 & 70.27 & $90 \%$ & 154 & 29 & 5 & 149 & $22.83 \%$ & 191 & 24 & 16000 & 428 \\
\hline $\operatorname{Jan} 6$ & Sat & 3.20 & 176 & 70.27 & $90 \%$ & 202 & 29 & 5 & 197 & $22.79 \%$ & 40 & 24 & 16000 & 586 \\
\hline $\operatorname{Jan} 7$ & Sun & 5.01 & 176 & 70.27 & $90 \%$ & 317 & 29 & 5 & 312 & $22.79 \%$ & 40 & 24 & 16000 & 857 \\
\hline $\operatorname{Jan} 8$ & $M$ & 7.75 & 836 & 70.27 & $90 \%$ & 490 & 29 & 5 & 485 & $22.81 \%$ & 191 & 24 & 16000 & 1152 \\
\hline $\operatorname{Jan} 9$ & $\mathrm{~T}$ & 2.15 & 836 & 70.27 & $90 \%$ & 136 & 29 & 5 & 131 & $22.85 \%$ & 191 & 24 & 16000 & 1092 \\
\hline $\operatorname{Jan} 10$ & w & 5.29 & 836 & 70.27 & $90 \%$ & 335 & 29 & 5 & 330 & $22.83 \%$ & 191 & 24 & 16000 & 1230 \\
\hline $\operatorname{Jan} 11$ & Th & 7.76 & 836 & 70.27 & $90 \%$ & 491 & 29 & 5 & 486 & $22.83 \%$ & 191 & 24 & 16000 & 1526 \\
\hline $\operatorname{Jan} 12$ & $\mathrm{~F}$ & 4.32 & 836 & 70.27 & $90 \%$ & 273 & 29 & 5 & 268 & $22.85 \%$ & 191 & 24 & 16000 & 1603 \\
\hline $\operatorname{Jan} 13$ & Sat & 9.19 & 176 & 70.27 & $90 \%$ & 581 & 29 & 5 & 576 & $22.85 \%$ & 40 & 24 & 16000 & 2138 \\
\hline $\operatorname{Jan} 14$ & Sun & 4.67 & 176 & 70.27 & $90 \%$ & 295 & 29 & 5 & 290 & $22.86 \%$ & 40 & 24 & 16000 & 2389 \\
\hline $\operatorname{Jan} 15$ & $M$ & 4.39 & 836 & 70.27 & $90 \%$ & 278 & 29 & 5 & 273 & $22.86 \%$ & 191 & 24 & 16000 & 2470 \\
\hline $\operatorname{Jan} 16$ & $\mathrm{~T}$ & 3.80 & 836 & 70.27 & $90 \%$ & 240 & 29 & 5 & 235 & $22.86 \%$ & 191 & 24 & 16000 & 2514 \\
\hline Jan 17 & W & 4.49 & 836 & 70.27 & $90 \%$ & 284 & 29 & 5 & 279 & $22.85 \%$ & 191 & 24 & 16000 & 2602 \\
\hline $\operatorname{Jan} 18$ & Th & 2.68 & 836 & 70.27 & $90 \%$ & 169 & 29 & 5 & 164 & $22.85 \%$ & 191 & 24 & 16000 & 2576 \\
\hline
\end{tabular}

FIGURE 12

CALCULATIONS IN TANK DESIGN TAB FOR WATER IN THE FIRST FLUSH SYSTEM AND WATER IN THE TANK

\section{Tank Design Outputs}

The final outputs of the model use calculated values for the stored water at each location after three years of rainwater catchment system operation. These outputs include a graph of the volume of water in storage versus the days in a design year, in addition to the length of the dry season, the number of days that the storage is empty, and the number of days into the dry season that the community will have water.

Viewing the results from the Preliminary and the Final Inputs shows how the level of accuracy from these estimates can impact the final results. Since the Preliminary Inputs are averaged values, the curves for the water level at each location have constant slopes between months, making them appear like irregular polygons. Meanwhile, the results using the Final Inputs are more accurate, showing a greater level of resolution due to the use of daily values. The estimation using the Final Inputs also indicated that the community would have on average 23 more days of water. Due to the area demand factor estimation, the amount of water at each location runs out around the same point in both cases.

Figure 13 shows the volume of water in storage, "Water in Tank", over a design year using data from the Preliminary Inputs tab. The horizontal lines on the graph represent the storage capacity at each location. To create this example, different storage volumes were used than what was decided for the Mkutani project. 
International Journal for Service Learning in Engineering, Humanitarian Engineering and Social Entrepreneurship Vol. 14, No. 3, Special Issue, pp. 80-97, Fall 2019

ISSN 1555-9033

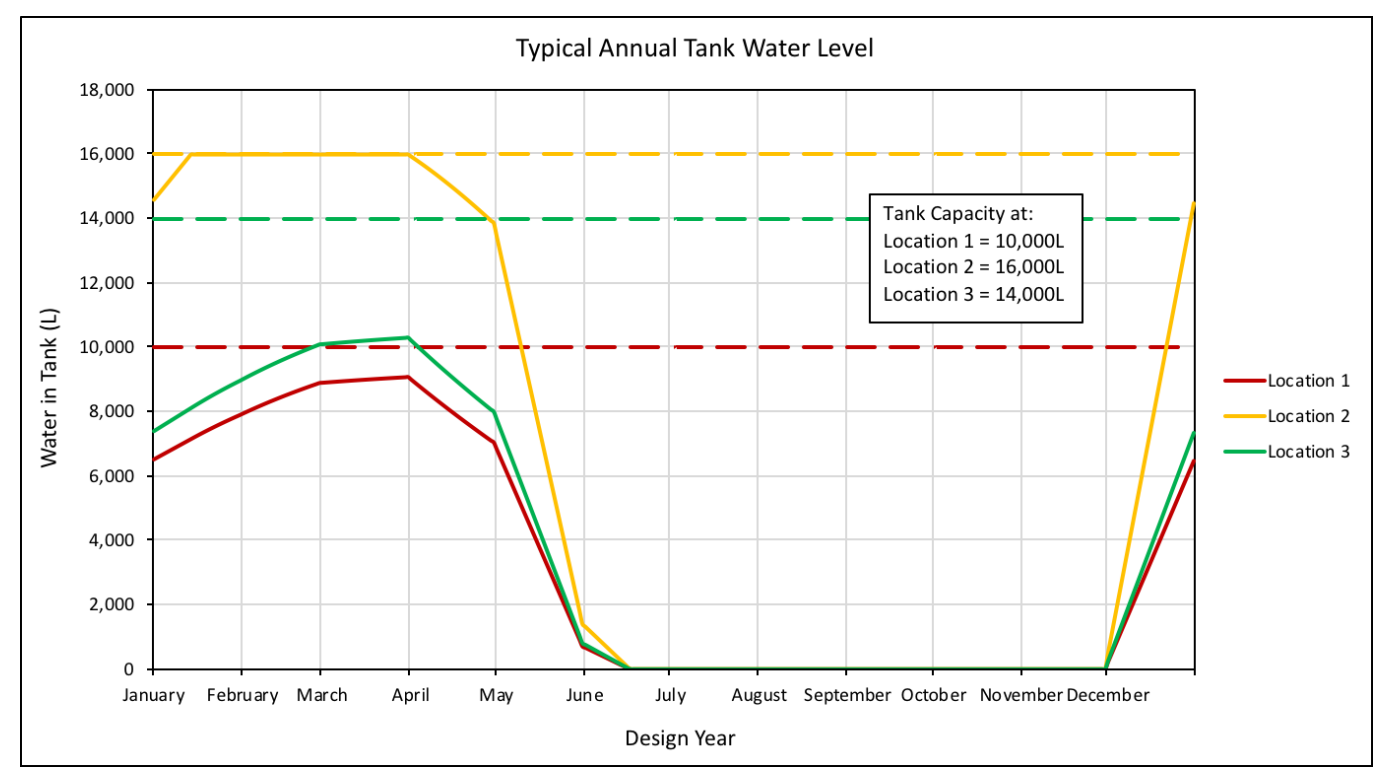

FIGURE 13

PLOT OF WATER LEVEL IN THE TANK(S) OVER A DESIGN YEAR USING PRELIMINARY INPUTS

Figure 14 shows the volume of water in storage, "Water in Tank", over a design year using data from the Final Inputs tab. The horizontal lines on the graph represent the storage capacity at each location. To create this example, different storage volumes were used than what was decided for the Mkutani project. This example uses the same volumes as those used in Figure 13.

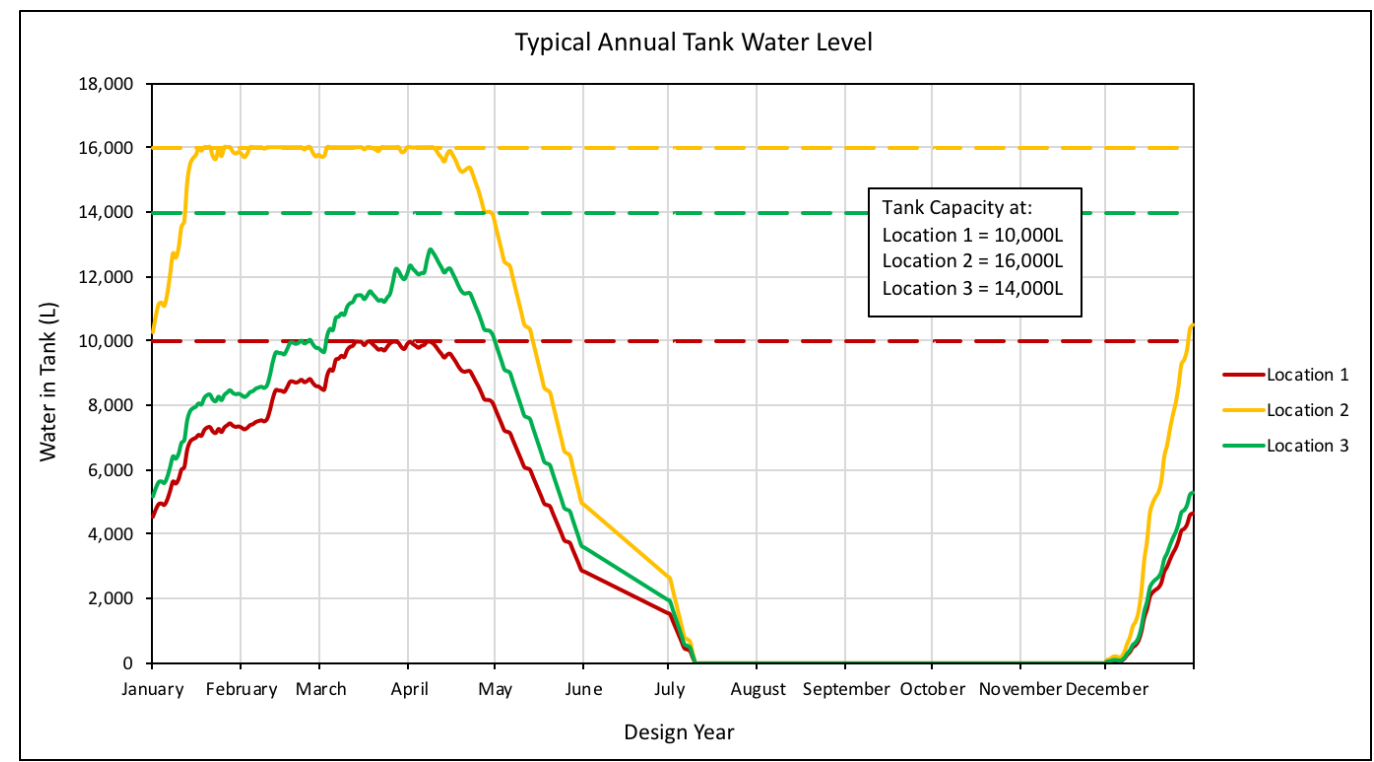

FIGURE 14

PLOT OF WATER LEVEL IN THE TANK(S) OVER A DESIGN YEAR USING FINAL INPUTS 
Figure 15 shows the results for the length of the dry season, number of days the storage is empty, and the number of days into the dry season the community will have water in storage. The left figure shows the results for the Preliminary Data while the right figure shows the results for the Final Data. While these have an equally long dry season estimate, the analysis based on the Preliminary Inputs claims that the storage will be empty 23 days longer than the analysis using the Final Inputs. Similarly, the preliminary dry season storage projection is 23 days less than the final analysis.

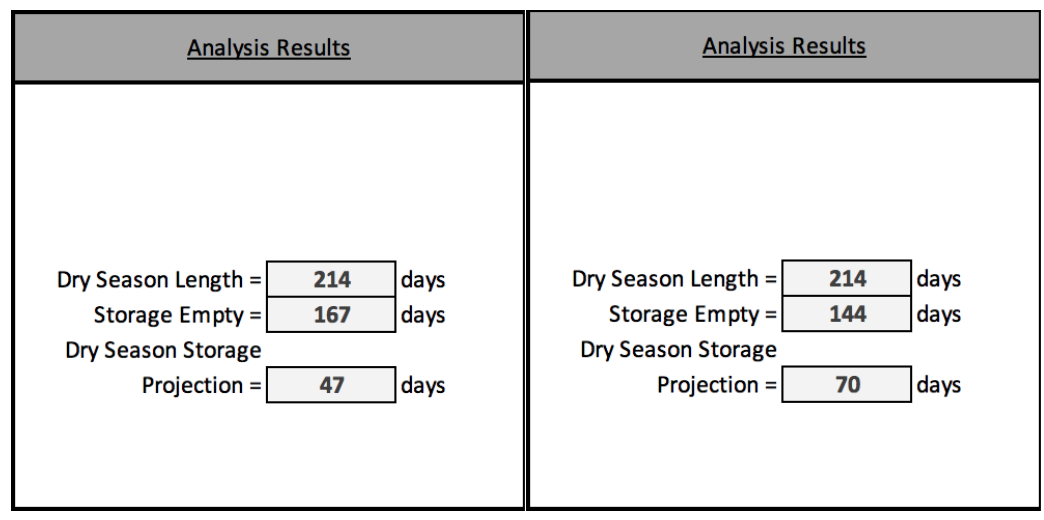

FIGURE 15

ANALYSIS RESULTS USING PRELIMINARY DATA (LEFT) AND FINAL DATA (RIGHT)

\section{Optimal Storage Volume}

To determine the optimal tank sizes or storage volume for a rainwater catchment system, it is important to examine the "Typical Annual Tank Water Level" plot and compare the level of water in the tank or storage (the curve) to the maximum storage capacity (the horizontal line). If the storage volume reaches its maximum capacity, then water is being lost due to overflow. This is well demonstrated by location 2 in Figure 14 where the yellow curve constantly meets the horizontal line. Meanwhile, the green curve for location 3 never meets this line, meaning that there is excess storage capacity that is never filled. The days without water can be minimized by preventing overflow and increasing the maximum storage volume; however, it is important to avoid excess storage capacity to not waste limited project funds and space. To improve this analysis, data from the dry and rainy design years from the "Average Rainfall Analysis Tool" can be used.

Figure 16 shows the volume of water in storage, "Water in the Tank", over a design year using data from the Final Inputs tab and optimal tank sizes for the Mkutani project. Location two is no longer limited by its maximum capacity as shown by the gap between the horizontal dashed lines and the peaks of the location curves. The horizontal line for Location 1 cannot be seen since Location 1 and Location 3 have the same total storage volume. Excess storage is included to allow for rainy years and reduced demand while avoiding waste. This new tank sizing results in a reduction in the number of days where the storage is empty to 117 days and the increase in number the days with water in the dry season to 97 days, as compared to the results from the model in 
Figure 14, which used smaller storage volumes at each location. As shown in Figure 14, the tanks are emptied in early July, while in Figure 16, the tanks are emptied in early August.

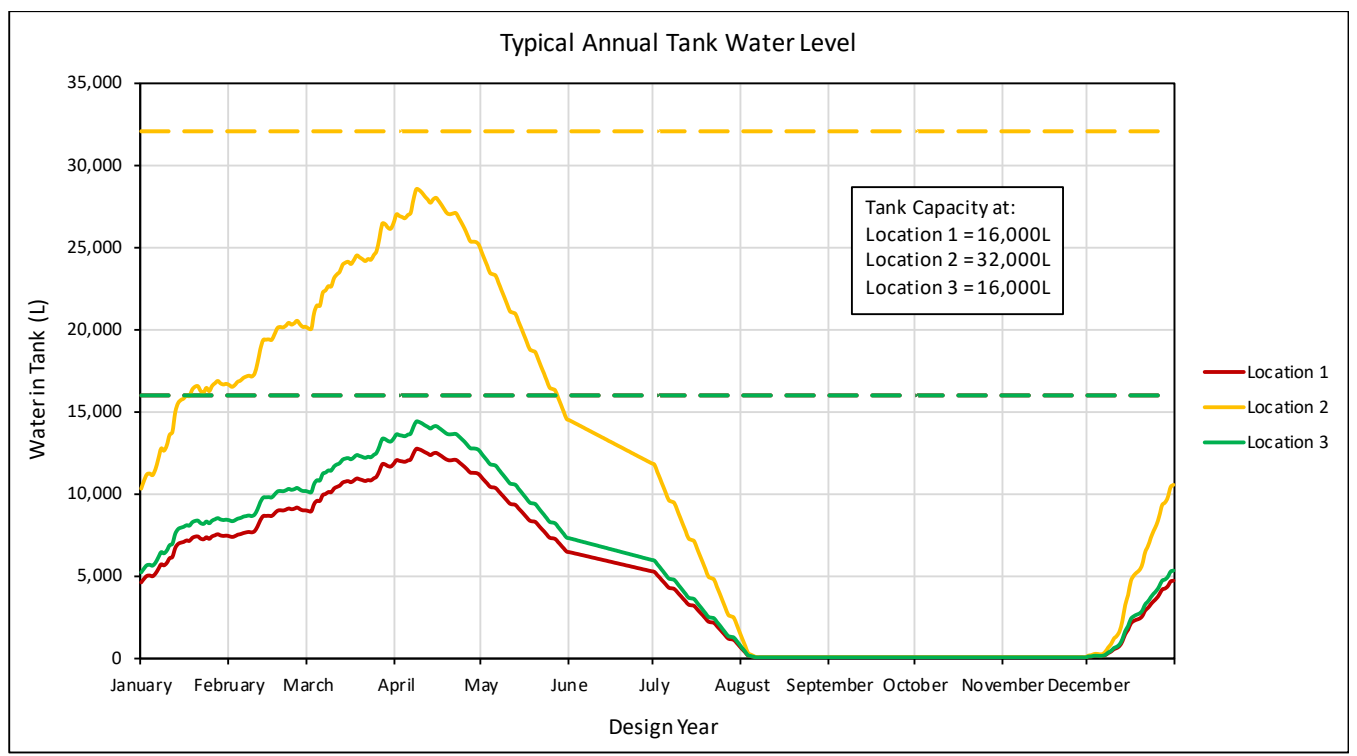

FIGURE 16

EXAMPLE OF OPTIMAL TANK SIZING FOR A PROJECT

\section{DISCUSSION}

Although an empirical verification of the model has yet to be performed, this tool can offer benefits for teams working on rainwater catchment projects. First, the model can improve work efficiency. This results from documentation that is easier to understand and more complete. The Preliminary Inputs combined with the Tank Design tab can output useful and easily reportable information for an early-stage design evaluation such as an alternatives analysis, a 30\% design report, or a design review. Meanwhile, using the results based on the Final Inputs tab is useful for documenting calculations for a mostly complete final project design, which can be used in a $90 \%$ design report or final design review. Since this model is based in Excel, which is generally available around the world and is compatible with many other freely available office suites like Google Sheets or OpenOffice, it can be used in-country in case design changes become necessary. This occurred during the summer of 2018 with the Mkutani project, where the estimated roof area was less than expected and the tool was used to determine whether the number of tanks continued to be an appropriate design choice at that location. The flexibility and ease of use was very important for the success of the Mkutani project and should be a benefit to other project teams for whom design changes on the ground are likely due to the discovery of new information on-site.

In addition, this model can increase project impact. Design teams can create more efficient and financially prudent systems due to the improved accuracy in determining an appropriate volume for water storage. Additionally, members of the community could learn how to use the tool, since Excel or compatible software is widely available, to plan how to ration water or to project forward how long their water supply will last. 
International Journal for Service Learning in Engineering, Humanitarian Engineering and Social Entrepreneurship Vol. 14, No. 3, Special Issue, pp. 80-97, Fall 2019

ISSN 1555-9033

Finally, the tool can be used as a method of verifying assumptions made about a project, where water level data from the estimation can be compared with water level data collected in country.

\section{ACKNOWLEDGMENT}

The authors would like to thank the following individuals for their input and feedback on the Rainwater Catchment modeling tool as well as useful discussions: Ben Holsapple, Eric Lundborg, and Scott Struck. Additionally, we would like to thank the financial contributors to the Mkutani Water Catchment Project: the Harvard School of Engineering and Applied Sciences, the Harvard President's Public Service Fund, the Gaffney Family Fund, and Engineers Without Borders USA.

\section{REFERENCES}

1 "Progress on Drinking Water, Sanitation and Hygiene: 2017 Update and Sdg Baselines." Geneva: World Health Organization and the United Nations Children's Fund, 2017.

2 "Drinking-Water Fact Sheet." World Health Organization, https://www.who.int/news-room/factsheets/detail/drinking-water.

$3 \quad$ "Safely Managed Drinking Water." Geneva: UNICEF and World Health Organization, 2016.

4 Graham, Jay P., Mitsuaki Hirai, and Seung-Sup Kim. "An Analysis of Water Collection Labor among Women and Children in 24 Sub-Saharan African Countries." PLOS ONE 11, no. 6 (2016): e0155981.

$5 \quad$ Nauges, Celine, and Jon Strand. "Water Hauling and Girls' School Attendance." 2013.

6 Bielefeldt, A. "Diverse Models for Incorporating Service Learning in Capstone Design." Paper presented at the Capstone Design Conference, 2010.

7 Lombardo, Christopher, and Suvai Gunasekaran. "Extracurricular Service Projects Prepare Engineering Students for Real World Problems." IDEAS 18 (2014): 71.

8 Lombardo, Christopher. "Engineering Sciences 91hfr - Humanitarian Design Projects." Cambridge, MA: Harvard School of Engineering and Applied Sciences, 2018.

9 "Guidelines for Drinking-Water Quality." Geneva: World Health Organization, 2008.

10 "The Texas Manual on Rainwater Harvesting." Austin, Texas: Texas Water Development Board, 2005.

11 Doyle, Kelly. "Sizing the First Flush and Its Effect on the Storage-Reliabilityyield Behavior of Rainwater Harvesting in Rwanda." Massachusetts Institute of Technology, 2008.

12 "Rwh System Sizing Calculator." American Rainwater Catchment Systems Association, https://www.arcsa.org/page/268.

13 Illian, Mark. "Roof and Gutters: Tank Sizing." The Center for Rainwater Harcesting, http://www.thecenterforrainwaterharvesting.org/2 roof gutters4.htm\#tank sizing.

14 "Catchment Area." Texas A\&M Agrilife Extension, https://rainwaterharvesting.tamu.edu/catchment-area/.

15 "Climate Change Knowledge Portal." The World Bank Group, http://sdwebx.worldbank.org/climateportal/index.cfm?page=global_map.

16 Reed, Brian, and Bob Reed. "How Much Water Is Needed in Emergencies." In TECHNICAL NOTES ON DRINKING-WATER, SANITATION AND HYGIENE IN EMERGENCIES, edited by Bob Reed. Geneva, Switzerland: Water, Engineering and Development Centre, Loughborough University and World Health Organization, 2013.

17 Lundborg, Eric, and Scott Strunk. "Demand Calculations for Mkutani." edited by Harvard SEAS Chapter of Engineers Without Borders USA, 2018.

18 "Global Weather Data for Swat." Texas A\&M University, https://globalweather.tamu.edu/.

19 Farreny, Ramon, Tito Morales-Pinzón, Albert Guisasola, Carlota Tayà, Joan Rieradevall, and Xavier Gabarrell. "Roof Selection for Rainwater Harvesting: Quantity and Quality Assessments in Spain." Water Research 45, no. 10 (2011): 3245-54.

20 Savou, Jesse. "To First Flush, or Not to First Flush." BlueBarrel Rainwater Catchment Systems, https://www.bluebarrelsystems.com/blog/first-flush-diverter/. 